\title{
Üvegszövetek deformációs és tönkremeneteli folyamatának szálkötegcella-elméleten alapuló modellezése
}

\section{Modelling the Deformation and the Failure Process of Glass Woven Fabrics Based on the Fibre-Bundle-Cells Theory}

\author{
Virág Ábris Dávid, ${ }^{1}$ Vas László Mihály, ${ }^{2}$ Molnár Kolos ${ }^{3}$ \\ ${ }^{1}$ Budapesti Müszaki és Gazdaságtudományi Egyetem, Gépészmérnöki Kar, Polimertechnika Tanszék, \\ Budapest, Magyarország,viraga@pt.bme.hu \\ ${ }^{2}$ Budapesti Müszaki és Gazdaságtudományi Egyetem, Gépészmérnöki Kar, Polimertechnika Tanszék, \\ Budapest, Magyarország, vas@pt.bme.hu \\ ${ }^{3}$ Budapesti Müszaki és Gazdaságtudományi Egyetem, Gépészmérnöki Kar, Polimertechnika Tanszék, \\ Budapest, Magyarország és MTA-BME Kompozittechnológiai Kutatócsoport, Budapest, Magyarország, \\ molnar@pt.bme.hu
}

\begin{abstract}
In this study, we modeled the deformation and failure behavior of different glass woven fabrics under uniaxial tension using the Fibre Bundle Cells-modeling method. The difference between the analytical, phenomenological model curve and the mean curve calculated from the measurement results was classified by the relative mean squared error (RMSE), which is closely related to the coefficient of determination. This value was less than $3.6 \%$ in all the examined cases, which indicated good modeling.
\end{abstract}

Keywords: FBC modeling, glass woven, tensile test.

\section{Összefoglalás}

Ebben a kutatásban különböző üvegszövetek egytengelyü húzás hatására mutatott deformációs és tönkremeneteli viselkedését modelleztük a szálkötegcella-alapú modellezéssel. Az általunk felállított analitikus, fenomenológiai modellgörbe és a mérési eredményekből meghatározott átlaggörbe közötti eltérést a determinációs együtthatóval szoros összefüggésben álló relatív átlagos négyzetes hibával (RÁNH) minősítettük. Ez az érték minden vizsgált esetben kevesebb mint 3,6\% volt, ami alapján a modellezés kifejezetten jónak tekinthető.

Kulcsszavak: szálkötegcella-alapú modellezés, üvegszövet, szakítóvizsgálat.

\section{Bevezetés}

Napjainkban a polimer kompozitok felhasználásának területe és mennyisége folyamatosan növekszik, és a szálerősített polimer kompozitokon kívül [1] egyre inkább előtérbe kerülnek a nano- [2], illetve biokompozitokkal [3], továbbá a kompozit szerkezetek tönkremenetelével foglalkozó kutatások [4]. A polimer kompozitok nagymértékű felhasználását mutatja többek között az a tény is, hogy manapság a repülőgépgyártás során felhasznált alapanyagok 50\%-a polimer kom- pozit (ha a motorokat nem vesszük figyelembe) [5]. Ezek jelentős része szöveterősítéssel készül, éppen ezért óriási igény van arra, hogy már a tervezési fázisban kellő pontossággal tudjuk modellezni ezen anyagok és termékek mechanikai viselkedését és tönkremenetelét. Ehhez azonban olyan szövetmodellekre van szükség, amelyek lehetővé teszik a szövetek mechanikai viselkedésének kellően pontos leírását. A szövetek modellezésére alapvetően kontinuum- vagy diszkrét elemes modelleket alkalmaznak. 


\subsection{Kontinuummodellek}

A szövetmodellek többsége kontinuummodell, amely a szövetet kontinuus anyagként kezeli. Hagyományosan a kompozitok mechanikai rétegmodelljeit használják a szövetek viselkedésének modellezésére. A szöveterősítésű kompozitok pontosabb leírásának érdekében számos olyan analitikus és végeselemes, 2D-s és 3D-s modellt dolgoztak ki, amelyek már valamilyen szinten figyelembe veszik a szövetek szálas szerkezetét és a szövés technológiájából adódó struktúrát. Ilyen például az Ishikawa által kidolgozott mozaikmodell [6], illetve hullámossági modell [7]. A mozaikmodell a szövetet először két, egymásra merőlegesen orientált rétegre osztja, majd a rétegeken belül elkülöníti a lánc- és vetülékfonalakat. A hullámossági modell már a fonalak folytonosságát, egyenetlenségét, illetve a lánc- és vetülékfonalak kereszteződését is figyelembe veszi, és a szövetet egy olyan ismétlődő egységgel írja le, amely három részből áll, mégpedig: a mozaikmodell fonalkereszteződéseinél is használt, kétrétegű elemből (a két réteg egymásra merőlegesen orientált), a hullámos szögállású elemből (amely a lánc- és vetülékfonalak tényleges kereszteződését írja le), továbbá egy, csak a mátrixanyagot tartalmazó elemből. Később ezekből az alapmodellekből indultak ki a 2D-s és 3D-s modellezések is, ráadásul a napjainkban alkalmazott modellek már idő- és hőmérsékletfüggő viselkedések leírására is alkalmazhatók [8].

\subsection{Diszkrét elemes modellek}

A diszkrét elemes modellek a szövetet véges számú csomópont (jellemzően tömegpont) hálózataként definiálják, a csomópontokat pedig általában adott tulajdonságú mechanikai elemek (például rugók, csillapítások stb.) kötik össze. Ilyen modell a Gräff és Kuzmina [9] által megalkotott, párhuzamosan kapcsolt rugók és csillapítások hálózatán alapuló modell. A modellben a diszkrét tömegpontokat különböző (strukturális, hajlító és nyíró) rugók kapcsolják össze. Azonban ezek nem egyszerü rugók, hanem lényegében Kelvin-Voigt-elemek (hiszen a rugóágak tartalmaznak csillapítást is). A modell a rugókat lineáris karakterisztikájúnak, a csillapításokat a sebességgel arányosnak tekinti, ugyanakkor nem veszi figyelembe a fonalak közötti súrlódást.

Egy másik, a szövetek leírására alkalmas, diszkrét elemes modell a Vas-féle szálkötegcella-modell [10, 11]. A szálkötegcella-alapú modellezési módszer egy modellkészletet kínál, amelynek elemeiből a szálas szerkezetek és a szálas szerkezetekkel erősített kompozitok viselkedésének leírására alkalmas rendszer építhető. A szálkötegcella-modell egy olyan diszkrét elemes modell, amely figyelembe veszi, hogy a kompozit erősítőanyagaként alkalmazott szövet nem kontinuum szerkezetű, és amelyben a szövetet alkotó fonalak (mint szálak) mikroszinten szálkötegeket (szálkötegcellákat) alkotnak. A modell a szövetek leírása esetén a szövet lánc- és vetülékfonalait tekinti szálkötegeknek. Makroszinten a szövetet diszkrét, statisztikus, lineáris vagy nemlineáris karakterisztikájú mechanikai elemek (szálkötegcellák) hálózataként írja le. A modell abból indul ki, hogy egy részben rendezett, azonos típusú szálakból álló szálköteg szálai kiindulási állapotuk és környezeti tulajdonságaik (befogási körülményeik) alapján osztályozhatók, valamint a környezetükkel együtt (vagy hasonló környezetbe) eltolhatók. Az azonos osztályokba sorolt szálak egy részköteget (azaz szálkötegcellát) alkotnak. Az ily módon előállított szálkötegcelláknak a nyújtás irányával párhuzamosan kapcsolt rendszere modellezi az eredeti köteg szerkezetét és szilárdságát, beleértve a teljes deformációs és tönkremeneteli folyamatot is.

\section{Az alkalmazott modell}

A modellezés során a lánc- és vetülékfonalakból álló valódi szövetet olyan modellel helyettesítettük, amelyben csak láncirányú fonalak vannak. Ezt megtehettük, hiszen a láncirányú szövetsáv szakítóvizsgálata során a vetülékfonalak lényegében nem vesznek fel terhelést, csupán a láncirányú fonalak térbeli elrendeződését és deformációs viselkedését módosítják. Ehhez tehát olyan modellkötegre van szükség, amelynek elemei olyan virtuális láncfonalak, amelyek a vetülékfonalak hatását is tartalmazzák. Az olyan próbatesteknél, ahol a láncfonalak párhuzamosak a terhelés irányával ( $0^{\circ}$-os próbatestek), „erős” modellfonalakat kapunk. Az olyan próbatesteknél, ahol a láncfonalak $+45^{\circ}$-os szöget zártak be a terhelés irányával ( $45^{\circ}$-os próbatestek), is megtehető ez a lépés, ebben az esetben azonban nincs a terhelés irányába eső fonal, így ekkor a hullámosság és a ferdeség deformációs viselkedést módosító hatásának eredményeként „gyenge” (láncirányú) modellfonalakat kapunk.

\subsection{Modellezés egy nemlineáris E-köteggel}

A $0^{\circ}$-os szövetsávokon végzett szakítóvizsgálatok modellezéséhez egy, a modellkészletben szereplő, nemlineáris húzókarakterisztikájú E-kö- 
teget használtunk. Az E-köteg egy jól rendezett, elasztikus, szakadó köteg, amelynek szálai egymástól függetlenek, mindkét végükön ideális befogásúak (vagyis nem csúsznak ki a befogásból és nem is szakadnak a befogásban), egymással és a nyújtás irányával is párhuzamosak, valamint nincsenek előfeszítve, azaz feszültségmentesek, de nem lazák. Ebben az esetben a húzókarakterisztikát (azaz az $\varepsilon$ kötegnyúlás és az $\mathrm{F}$ kötegre ható erő közötti kapcsolatot) $\left(f(\varepsilon), \mathrm{N} \cdot \mathrm{g}-1 \cdot \mathrm{m}^{2}\right)$ az (1) öszszefüggés írja le, $a>0\left(\mathrm{~N} \cdot \mathrm{g}^{-1} \cdot \mathrm{m}^{2}\right), b>0\left(\mathrm{~N} \cdot \mathrm{g}^{-1} \cdot \mathrm{m}^{2}\right)$ a fonal hullámosságának és a szövetsáv redőződésének a húzókarakterisztikára gyakorolt befolyását képviselő paraméterek, $c>0\left(\mathrm{~N} \cdot \mathrm{g}^{-1} \cdot \mathrm{m}^{2}\right)$ pedig a húzómerevség aszimptotikus értéke:

$$
f(\varepsilon)=c \varepsilon+a\left(1-e^{-b \varepsilon}\right)
$$

Látható, hogy $a=0$ és/vagy $b=0$ esetén az (1) egyenlet tartalmazza a lineáris esetet is.

$\mathrm{Az}$ (1) egyenlet azonban - mint a húzókarakterisztikák általában - csupán a hibamentes müködést írja le, a legtöbb mechanikai modellel ezt tudjuk meghatározni. A szálkötegcella-alapú modellezés viszont feltételezi, hogy a vizsgált anyagban vannak hibák. Ezeket egy ún. megbízhatósági függvénnyel $(g(\varepsilon))(2)$ vesszük figyelembe, ahol $\varepsilon$ a modellfonal fajlagos nyúlása, $\varepsilon_{S}$ a modellfonal fajlagos szakadási nyúlása, $Q_{\varepsilon_{S}}$ pedig a fajlagos szakadási nyúlás eloszlásfüggvénye:

$$
g(\varepsilon)=\left(1-Q_{\varepsilon_{S}}(\varepsilon)\right)
$$

Ebben az esetben tehát a megbízhatósági függvény a fajlagos szakadási nyúlás komplementer eloszlásfüggvénye. A megbízhatósági függvény az adott $\varepsilon$-hoz tartozó terhelési szinten megadja a még működő, vagyis ép szálak, fonalak arányát. Jelen esetben a modellfonalak fajlagos szakadási nyúlását $\left(\varepsilon_{S}\right)$ normális eloszlásúnak feltételeztük.

Az (1) és (2) egyenletek segítségével a $\sigma(\varepsilon)$ fajlagos húzófeszültség (amely az erő és a vizsgált anyag területi sűrüségének hányadosa) előállítható úgy, mint az $f(\varepsilon)$ húzókarakterisztika és a $g(\varepsilon)$ megbízhatósági függvény szorzata (3), amely bonyolultabb számítások esetén lényegesen lecsökkenti a számítások műveletigényét:

$$
\sigma(\varepsilon)=f(\varepsilon) \cdot g(\varepsilon)
$$

\subsection{Modellezés két, párhuzamosan kap- csolt, nemlineáris E-köteggel}

A 45-os szögállású szövetsávok egytengelyü húzás hatására mutatott deformációs és tönkremeneteli viselkedését leíró átlaggörbék modellezéséhez minden esetben két, párhuzamosan kapcsolt, nemlineáris E-köteget használtunk. A két köteg alkalmazására azért volt szükség, mert a görbék alakjából következően az egyköteges leírás esetén nagyon pontatlan eredményt kaptunk volna.

$\mathrm{Ez}$ az eset nagyon hasonló az egyköteges esethez, a különbség csupán annyi, hogy ekkor a húzókarakterisztika leírása nem az (1), hanem a (4) egyenlettel történik, ahol $p_{1}$ és $p_{2}$ olyan - szálszámokkal arányos - súlyozási tényező, amelyekre igaz, hogy $p_{1}+p_{2}=1$ :

$$
f(\varepsilon)=p_{1} \cdot f_{1}(\varepsilon)+p_{2} \cdot f_{2}(\varepsilon)
$$

ahol az egyes kötegek karakterisztikája (5):

$$
f_{i}(\varepsilon)=\left\{\begin{array}{rr}
c_{i} \cdot\left(\varepsilon-d_{i}\right)+a_{i}\left(1-e^{-b_{i} \cdot\left(\varepsilon-d_{i}\right)}\right), & \text { ha } \varepsilon \geq d_{i} \\
0 & , \text { ha } \varepsilon<d_{i}
\end{array}\right.
$$

ahol $i \in\{1,2\}$, d pedig egy eltolás, amely az egyik vagy akár mindkét esetben zérus. Látható, hogy az (5) összefüggés magában foglalja az egyköteges esetet is, hiszen egy köteg esetén $d=0$, két köteg esetén pedig például az egyik kötegnél $d>0$, a másik kötegnél $d=0$. A kétköteges esetben tehát a húzókarakterisztika négyparaméteres.

A fajlagos húzófeszültség ebben az esetben is a húzókarakterisztika és a megbízhatósági függvény szorzatának a két, nemlineáris E-kötegre $\left(E_{1}\right.$ és $E_{2}$ ) vett, súlyozott összegeként állítható elő (6) szerint:

$$
\begin{aligned}
\sigma(\varepsilon) & =\sigma_{E_{1}}(\varepsilon)+\sigma_{E_{2}}(\varepsilon) \\
& =p_{1} \cdot \sigma_{1}(\varepsilon)+p_{2} \cdot \sigma_{2}(\varepsilon) \\
& =p_{1} \cdot f_{1}(\varepsilon) \cdot g_{1}(\varepsilon)+p_{2} \cdot f_{2}(\varepsilon) \cdot g_{2}(\varepsilon)
\end{aligned}
$$

\section{A vizsgált anyagok és az alkalmazott módszerek}

A kutatás során a Unique Textiles gyártótól származó UTE195P (területi sűrüség: 195 g/m², kötésminta: vászon) és UTE195T (területi sűrűség: $195 \mathrm{~g} / \mathrm{m}^{2}$, kötésminta: sávoly) típusú üvegszöveteket vizsgáltunk. A szövetekből láncirányú ( $0^{\circ}$-os) és $\pm 45^{\circ}$-os mintákat készítettünk elő, melyek szélessége és hossza rendre 50 és $200 \mathrm{~mm}$ volt. A minták egytengelyű szakítóvizsgálatát univerzális szakítógépen (gyártó: Zwick, típus: Z005) végeztük. A befogási hossz $100 \mathrm{~mm}$, a vizsgálati sebesség $25 \mathrm{~mm} / \mathrm{min}$ volt, a vizsgálat során az erőt és a keresztfej elmozdulását (továbbiakban elmozdulás) regisztráltuk. A szálkötegcella-alapú modellezést a szakítóvizsgálatok alapján végeztük. Az öt erő-keresztfej elmozdulásgörbét először átparamétereztük fajlagos feszültség (a mért erő és a próbatest területi sűrűségének hányadosa) - fajlagos nyúlás (a próbatest aktuális és kezdeti befogási hosszának hányadosa) görbére, majd minden esetben meghatároztuk az ún. simított átlaggörbét (ezt mozgó átlagos simítás- 
sal állítottuk elő, ahol a simítási ablak szélessége $\varepsilon=0,01$ volt). Az így kapott átlaggörbéket használtuk a modellezéshez. Az (1)-(6) összefüggéseket alkalmazva elvégeztük a szálkötegcella-alapú modellezést a teljes erő-keresztfej elmozdulásgörbére. Az (1) és (5) összefüggésekben szereplő modellparamétereket $\left(a_{i}, b_{i}, c_{i}, d_{i}\right.$ és $\left.p_{i}\right)$ iterációs módszerrel optimalizáltuk, oly módon, hogy a modellgörbe és a mérésekből meghatározott átlaggörbe közötti, a determinációs együtthatóval szoros összefüggésben álló, (7) összefüggés alapján meghatározott relatív átlagos négyzetes hiba (RÁNH) minimális legyen:

$$
R \text { ÁNH }=\sqrt{\frac{1}{n} \cdot \sum_{i=1}^{n}\left(\sigma_{m e ́ r t ~}\left(\varepsilon_{i}\right)-\left(\sigma\left(\varepsilon_{i}\right)\right)^{2}\right.}
$$

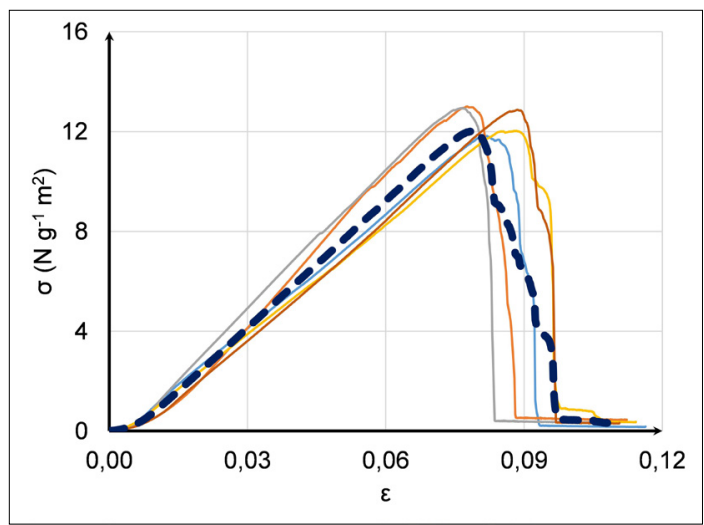

1. ábra. A sávolykötésü szövet láncirányú terheléssel végzett vizsgálattal kapott szakítógörbéi és azok simított átlaggörbéje (szaggatott vonallal)

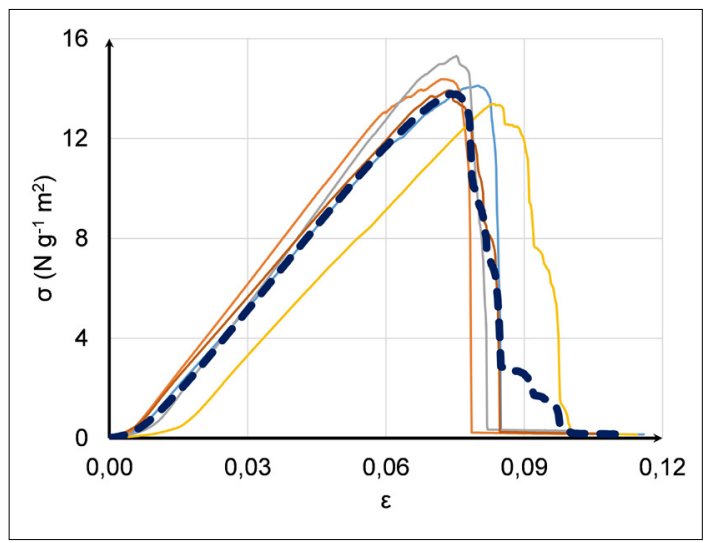

2. ábra. A sávolykötésü szövet láncirányú terheléssel végzett vizsgálattal kapott szakítógörbéi és azok simított átlaggörbéje (szaggatott vonallal) ahol $n$ a mérési pontok számát, $\sigma_{\text {mért }}$ a mért erőértékekből számított fajlagos feszültséget, az $\varepsilon_{i}$ pedig az adott pontban mért feszültséghez tartozó nyúlásértéket jelenti.

\section{A szakítóvizsgálatok és a modellezés eredményei}

A szakítóvizsgálatokból számított fajlagos feszültség $(\sigma)$ versus fajlagos nyúlás $(\varepsilon)$ görbéket a vizsgált szövetek esetén az 1-4. ábrák mutatják. Az ábrákon a szaggatott vonal a modellezéshez szükséges, simított átlaggörbét jelöli.

A görbéken látható, hogy az azonos méretű, de eltérő kötésmintájú próbatestek erőmaximumai között láncirányú terhelés esetében nincs jelentős különbség, azonban a \pm 45 fokos esetben nagyságrendi különbség van. Mivel ennél a vizsgálatnál

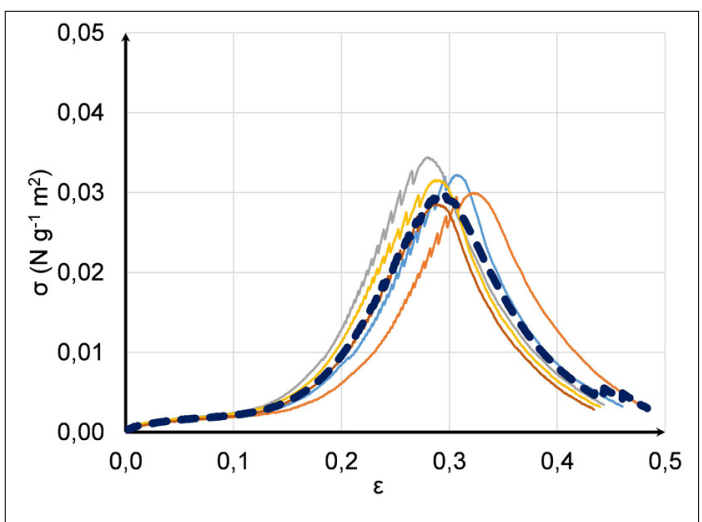

3 ábra. A vászonkötésü szövet a láncirányhoz képesti -45 fok irányú terheléssel végzett vizsgálattal kapott szakítógörbéi és azok simított átlaggörbéje (szaggatott vonallal)

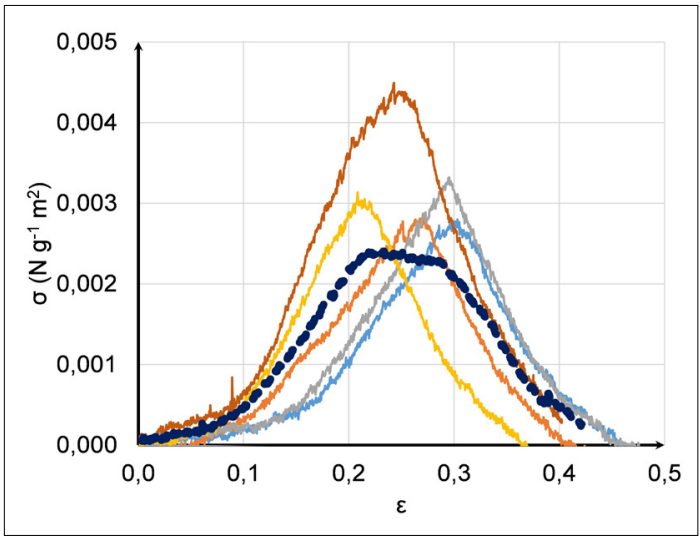

4. ábra. A sávolykötésü szövet a láncirányhoz képesti -45 fok irányú terheléssel végzett vizsgálattal kapott szakítógörbéi és azok simított átlaggörbéje (szaggatott vonallal) 
nincs a terhelés irányába eső fonal, ezért az erőmaximumot a szövetek kötésmintája határozza meg, hiszen minden más paraméterük azonos. Ezek a mérési eredmények is bizonyítják azt az ismert tényt, hogy a sávolyszövés egy sokkal lazább szerkezetet eredményez, amiből következik az is, hogy sokkal könnyebb bonyolult térformákra alakítani. Természetesen ez a különbség beágyazott erősítőanyagként való alkalmazásakor is jelentkezik a kompozitra jellemző mechanikai tulajdonságokban.

Az egyes mérési görbékből meghatározott simított átlaggörbék és a modellezett görbék kapcsolatát az 5-8. ábrák mutatják.

A modellezés számszerüsített eredményeit az

1. táblázat tartalmazza. A táblázatban az $a, b$,

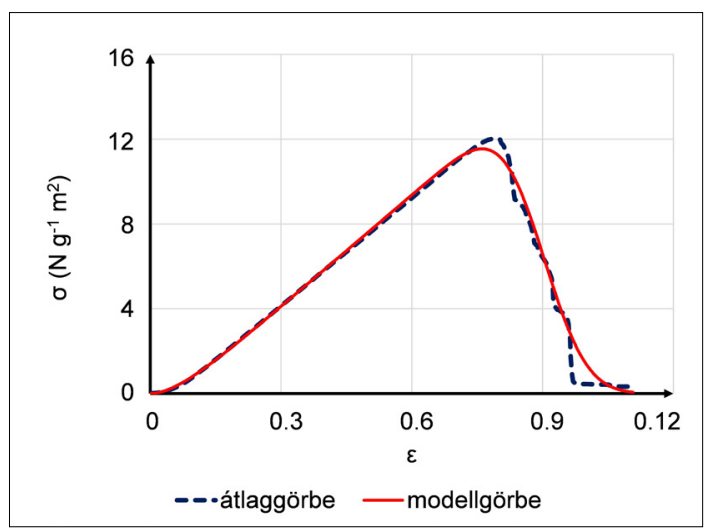

5. ábra. A vászonkötésű szövet láncirányú terheléssel végzett szakítóvizsgálataiból meghatározott simított átlaggörbéje és modellgörbéje

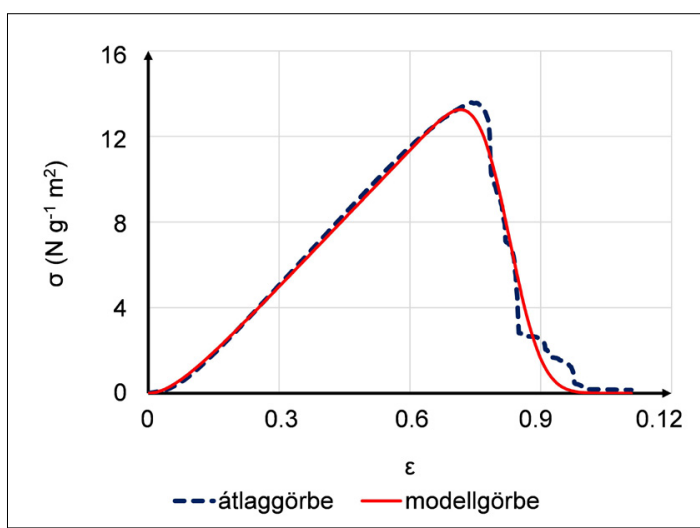

6. ábra. A sávolykötésű szövet láncirányú terheléssel végzett szakítóvizsgálataiból meghatározott simított átlaggörbéje és modellgörbéje $c$, $d$ paraméterek az (1) és (5) összefüggésekben szereplő változók, az $E\left(\varepsilon_{S}\right), D\left(\varepsilon_{S}\right)$ és $V\left(\varepsilon_{S}\right)$ pedig rendre a fajlagos szakadási nyúlás várható értéke, szórása és relatív szórása. A modellgörbék és a mérésekből meghatározott simított átlaggörbék viszonyának jellemzésére, azaz a modellezés jóságának meghatározására a relatív átlagos négyzetes hibát (RÁNH) használtuk.

Az 1. táblázat alapján látható, hogy a mérésekből meghatározott simított átlaggörbe és a szálkötegcella-elmélettel számolt görbe közötti relatív átlagos négyzetes hiba minden esetben kisebb, mint 3,6\%. Ezen eredmények alapján a modellezés kifejezetten jónak mondható, azaz a modellezett görbe kellően jól közelíti a mérésekből meghatározott, simított átlaggörbét.

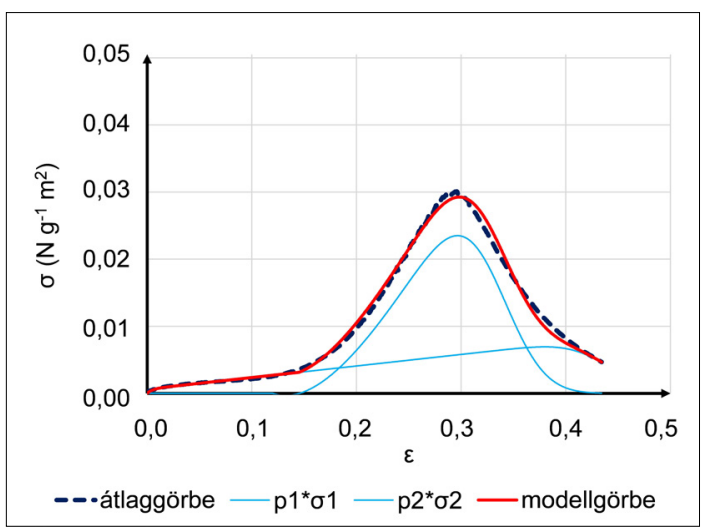

7. ábra. A vászonkötésü szövet a láncirányhoz képesti -45 fok irányú terheléssel végzett szakítóvizsgálataiból meghatározott simított átlaggörbéje és modellgörbéje

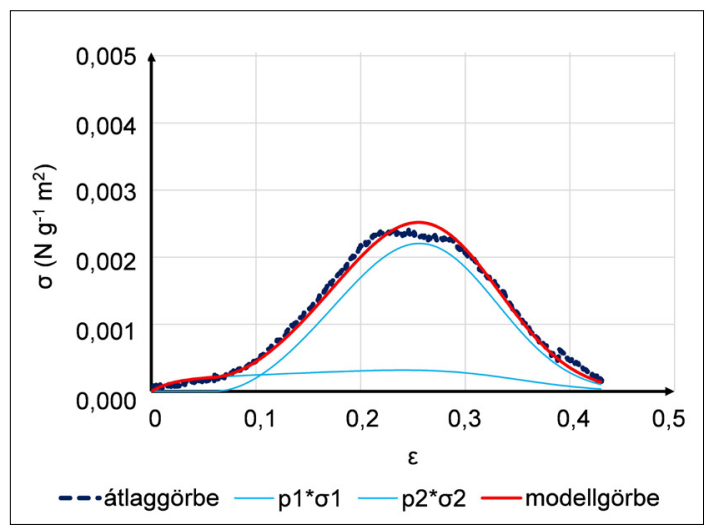

8. ábra. A sávolykötésü szövet a láncirányhoz képesti -45 fok irányú terheléssel végzett szakitóvizsgálataiból meghatározott simított átlaggörbéje és modellgörbéje 
1. táblázat. A szövetsávok modellezését jellemző paraméterek

\begin{tabular}{|c|c|c|c|c|c|c|c|c|c|c|c|}
\hline & & & \multicolumn{9}{|c|}{ MODELLPARAMÉTEREK } \\
\hline \multicolumn{3}{|c|}{ Minta és befogás } & \multirow{2}{*}{\begin{tabular}{|c|}
$\begin{array}{c}\text { Modell- } \\
\text { szerkezet }\end{array}$ \\
$\begin{array}{c}\text { Komponens } \\
\text { súly, } \\
\text { p }\end{array}$ \\
\end{tabular}} & \multicolumn{4}{|c|}{ Húzókarakterisztika - ép müködés } & \multicolumn{3}{|c|}{ Tönkremenetel } & \multirow{2}{*}{$\begin{array}{c}\text { Illesz- } \\
\text { kedés } \\
\text { RÁNH } \\
\text { (\%) }\end{array}$} \\
\hline Minta & $\begin{array}{c}\text { Befogási } \\
\text { hossz } \\
(\mathrm{mm})\end{array}$ & $\begin{array}{c}\text { Irány- } \\
\text { szög } \\
\left({ }^{\circ}\right)\end{array}$ & & $\stackrel{a}{\left(N \cdot g^{-1} \cdot m^{2}\right)}$ & $\underset{\left(\mathrm{N} \cdot \mathrm{g}^{-1} \cdot \mathrm{m}^{2}\right)}{\mathrm{b}}$ & $\begin{array}{c}\mathrm{c} \\
\left(\mathrm{N} \cdot \mathrm{g}^{-1} \cdot \mathrm{m}^{2}\right)\end{array}$ & d & $\mathrm{E}\left(\varepsilon_{\mathrm{s}}\right)$ & $\mathbf{D}\left(\varepsilon_{\mathrm{s}}\right)$ & $\begin{array}{c}\mathrm{V}\left(\varepsilon_{\mathrm{S}}\right) \\
(\%)\end{array}$ & \\
\hline Vászon & 100 & 0 & 1,00 & -220 & 1,5 & 330 & 0 & 0,09 & 0,008 & 9,0 & 3,05 \\
\hline Sávoly & 100 & 0 & 1,00 & -267 & 1,5 & 400 & 0 & 0,08 & 0,006 & 7,1 & 3,49 \\
\hline \multirow{2}{*}{ Vászon } & \multirow{2}{*}{100} & \multirow{2}{*}{45} & 0,40 & 0,3 & 2,0 & 0,08 & 0 & 0,44 & 0,033 & 7,5 & \multirow{2}{*}{2,10} \\
\hline & & & 0,60 & $-8,3$ & 0,1 & 0,92 & 12 & 0,33 & 0,033 & 10,0 & \\
\hline \multirow{2}{*}{ Sávoly } & \multirow{2}{*}{100} & \multirow{2}{*}{45} & 0,12 & 0,3 & 0,5 & 0,01 & 0 & 0,34 & 0,063 & 18,5 & \multirow{2}{*}{3,59} \\
\hline & & & 0,88 & $-0,6$ & 0,1 & 0,06 & 6 & 0,29 & 0,063 & 21,7 & \\
\hline
\end{tabular}

\section{Következtetések}

A szálkötegcella-alapú modellezési módszer felhasználásával olyan diszkrét elemes, analitikus, fenomenológiai modellt hoztunk létre, amely alkalmas a kompozit erősítőszövetek egytengelyü szakítóvizsgálat során mutatott deformációs és tönkremeneteli viselkedésének mechanikai modellezésére. Az anyagonként öt szakítóvizsgálatból meghatározott simított átlaggörbe és az általunk felállított modellből számított görbe közötti relatív átlagos négyzetes hiba minden esetben kevesebb mint 3,6\%-ra adódott. Ezek alapján a modellezés kifejezetten jónak mondható, és megállapítható, hogy ez egy gyors, egyszerü, kis számításigényű módszer, amely alkalmas a szövetek egytengelyű húzás hatására mutatott deformációs és tönkremeneteli viselkedésének leírására.

\section{Köszönetnyilvánítás}

A kutatás az Innovációs és Technológiai Minisztérium ÚNKP-20-3 és ÚNKP-20-5 kódszámú Új Nemzeti Kiválóság Programjának szakmai támogatásával készült. A jelen publikációban megjelenő kutatások az ITM NKFIA által nyújtott, TKP2020 NKA jelű támogatásból, az NKFIH által kibocsátott támogatói okirat alapján valósultak meg (projektazonosító: TKP2020 BME-NKA).

\section{Szakirodalmi hivatkozások}

[1] Rajak D. K., Pagar D. D., Menezes P. L. Linul E.: Fiber-Reinforced Polymer Composites: Manufacturing, Properties, and Applications. Polymers, 11/10. (2019) 1667.

https://doi.org/10.3390/polym11101667

[2] Singh R., Shrivastava A. K., Bajpai A. K.: CdSe reinforced polythiophene nanocomposites as excellent materials for diode applications. eXPRESS Polymer Letters, 15/1. (2021) 45-57.

https://doi.org/10.3144/expresspolymlett.2021.6
[3] Akintayo O. S., Olajide J. L., Betiku O. T., Egoh A. J., Adegbesan O. O., Daramola O. O., Sadiku E. R., Desai D. A.: Poly(lactic acid)-silkworm silk fibre/ fibroin bio-composites: A review of their processing, properties, and nascent applications. eXPRESS Polymer Letters, 14/10. (2020) 924-951.

https://doi.org/10.3144/expresspolymlett.2020.76

[4] Takács L., Szabó F.: Experimental and Numerical Failure Analysis of Adhesive Joint of Glass Fiber Reinforced Polymer Composite. Periodica Polytechnica Mechanical Engineering, 64/1. (2020) 88-95.

https://doi.org/10.3311/PPme.15106

[5] 1001Crash.com: Worries about new composite made airplane, 2011. (letöltve: 2021. február 17.). http://www.1001crash.com/index-page-composite-lg-2.html

[6] Ishikawa T.: Anti-symmetric Elastic Properties of Composite Plates of Satin Weave Cloth. Fiber Science and Technology, 15/2. (1981) 127-145.

https://doi.org/10.1016/0015-0568(81)90066-X

[7] Ishikawa T., Chou T. W.: One-dimensional Micromechanical Analysis of Woven Fabric Composites. AIAA, 21/12. (1983) 1714-1721.

https://doi.org/10.2514/3.8314

[8] Shrotriya P., Sottos N. R.: Viscoelastic Response of Woven Composite Substrates. Composites Science and Technology, 65/3-4. (2005) 621-634.

https://doi.org/10.1016/j.compscitech.2004.09.002

[9] Gräff J., Kuzmina J.: Cloth Simulation Using Mass and Spring Model. In: Material Science. Mechanical Engineering 2004. Proceeding of $4^{\text {th }}$ Conference on Mechanical Engineering, Budapest, Hungary, Budapest, BUTE, (2004) 443-447.

[10] Vas L. M.: Idealizált statisztikus szálkötegcellák és alkalmazásuk szálas szerkezetek, kompozitok modellezésére. MTA doktori értekezés (2007).

[11] Vas L. M., Tamás P.: Modelling Method Based on Idealised Fibre Bundles. Plastics, Rubber and Composites, 37/5-6. (2008) 233-239.

https://doi.org/10.1179/174328908X309411 